\title{
The Level of Maternal Knowledge about Complications in Pregnancy toward the Increase of Low Birth Weight Cases
}

\author{
Aisyah Apriliciciliana Aryani ${ }^{1 *}$, Besral $^{2}$ \\ 1Biostatistics, Department of Public Health, Faculty of Health Sciences, Jenderal \\ Soedirman University, Indonesia \\ 2Department of Biostatistics and Population Studies, Faculty of Health Sciences, Jenderal \\ Soedirman University, Indonesia
}

*corresponding author, e-mail: aisyah.apriliciciliana@unsoed.ac.id

Received: 13/04/2020; published: 29/09/2020

\begin{abstract}
Background: Based on Metro City Health Office reports, there was an increase in the proportion of LBW cases from 75 cases per 1.000 live births in 2015 to 87 cases per 1.000 live births in 2016. Metro City Health Service stated that one of the causes was the low level of maternal knowledge, especially regarding the consumption of balanced nutrition during pregnancy. This study aimed to investigate the relationship between the level of maternal knowledge and Low Birth Weight (LBW). Method: The study design was case-control, where low birth weight as a case and normal weight as a control. Study sample was 102 , consisting of 51 cases and 51 control. Dependent variable was low birth weight, independent variable was the level of maternal knowledge. Data was obtained by interviewing the mothers, and secondary data was collected from community health center records. Data was analysed by bivariate and multivariate analysis. Results: Bivariate analysis showed that the OR level of maternal knowledge was 2,598 (95\% Cl: 1,126-5,995). The results of multivariate analysis showed that OR level of maternal knowledge was 2,646 (95\% Cl: 1,092-6,410). Conclusion: Mother's level of knowledge is a risk factor for LBW in Metro City.
\end{abstract}

Keywords: level of maternal knowledge; LBW; case control; metro

Copyright $@ 2013$ Universitas Ahmad Dahlan. All rights reserved.

\section{Introduction}

The results of Basic Health Research (Riskesdas) in 2018 showed that the prevalence of Low Birth Weight (LBW) in Indonesia was $6,2 \%$ and the prevalence of LBW in Lampung Province was 6\% (1). Based on a report from the Lampung Provincial Health Office in 2015, the proportion of LBW occurred in Lampung Province was 25 per 1000 of live births, in which Metro City was ranked the third highest with the proportion of LBW of 75 per 1,000 of live births. In 2016, the Metro City Health Office reported that there was an increase in the proportion of LBW cases to 87 per 1,000 of live births. The highest number of LBW cases was at the Yosomulyo Health Center (41 cases), and the lowest was at the Mulyojati Health Center (11 cases) (2).

LBW babies are babies born with a birth weight of less than 2,500 grams regardless of gestation (13). LBW is divided into two categories; LBW due to prematurity (gestation less than 37 weeks) or LBW due to intrauterine growth retardation (IUGR) that is a full term baby born underweight (2). LBW still becomes a public health problem in many countries, because it is considered to be one of the factors causing infant mortality. Previous research stated that babies with LBW have risk of death under the age of 1 which is 17 times greater than babies born with normal birth weight. This is possible because the body organs of LBW babies have not perfectly developed (3). The causes of LBW are not only influenced by the gestation and the growth of the fetus in the uterus, but also other factors such as socio-demographic factors related to the mother's age, socioeconomic level, occupation and maternal factors such as parity and complications during pregnancy. 
Previous research also stated that the level of maternal knowledge regarding complications in pregnancy was also a risk factor for LBW (4).

A complication is a deviation from the normal state that can directly cause morbidity and mortality for both mother and baby (16). Several types of complications commonly accompany pregnancy such as pre-eclampsia, ectopic pregnancy, bleeding, placenta previa and gestational diabetes (15). Pre-eclampsia or also known as toxemia is a condition in which pregnancy is accompanied by a rise in blood pressure even without a previous history of high blood pressure in the expectant mother. An ectopic pregnancy occurs when the fetus develops outside the uterus. After fertilization, the zygote resulting from the combination of sperm and ovum cells attaches to tissues other than the uterine wall and then stays and grows in these tissues. This fetal development can occur in the fallopian tubes, service canals, pelvis or abdominal cavity. Bleeding during pregnancy is vaginal bleeding that occurs during pregnancy which generally refers to abnormal bleeding that is not part of menstruation. Vaginal bleeding is common in the first trimester of pregnancy and affects 20-30 percent of total pregnancies, but this still needs to be aware of. Placenta previa is a condition in which the fertilized egg rolls and attaches close to the cervix or covers the cervix so that the placenta automatically closes the birth canal. Gestational diabetes (DG) is a condition of high blood sugar of the expectant mother, with or without a previous diabetes history. This complication can affect at least 4 percent of the total number of pregnant women (15).

Data from the Metro City Health Office in 2018 stated that there were 584 pregnant women who experienced obstetric complications. The highest rate of complications during pregnancy was in the working area of the Yosomulyo Health Center with 108 people (18.49\%), Metro Health Center with 78 people (13.35\%), and Yosodadi Health Center with 60 people (10.27\%). Meanwhile, the highest number of babies born with LBW was in the working area of Yosomulyo Health Center with 39 babies (18.05\%), Metro Health Center with 26 babies (12.03\%), and Yosodadi Health Center with 22 babies (10.18\%) (13).

Based on a preliminary study conducted on 10 pregnant women, it can be seen that 5 pregnant women knew about pregnancy complications but did not really understand about the dangers and risks that will occur, while 5 pregnant women did not know about the risks if the complications occur during pregnancy. Seeing the high data on the incidence of complications during pregnancy, the proportion of LBW and the importance of examining the level of mother's knowledge about complications in pregnancy in Metro City, it is necessary to conduct a study on the effect of the level of maternal knowledge about complications in pregnancy toward the incidence of LBW.

\section{Method}

This study used a case control design which aims to determine the effect of the level of maternal knowledge about complications in pregnancy toward the incidence of LBW in Metro City. Metro City consists of 5 (five) sub-districts; Central Metro, West Metro, North Metro, East Metro and South Metro. The total population of Metro City in 2016 was 160,729 people consisting of 80,300 male residents and 80,429 female residents. The case was a mother who gave birth to a LBW baby with a gestational age of 37-42 weeks (aterm), while the control was a mother who gave birth to a normal weight baby. The sources of case and control were from the register book of the cohort of infants and pregnant women in all health centers in Metro City from January to December 2017 . The sample size was determined based on the level of significance of 0.05 , power $0.84(80 \%)$; the proportion of risk factors in the LBW group was 18\%; the proportion of risk factors in the non-LBW group was 3\%; so that the sample size obtained was 102 consisting of 51 cases and 51 controls. The selection of case and control samples used systematic random sampling.

The dependent variable in this study was LBW and the independent variable (risk factor) was the level of mother's knowledge about complications in pregnancy. Data were collected using a questionnaire. The level of maternal knowledge about complications in pregnancy was measured by the criteria showing that the respondents know about swelling of feet, hands and face are danger signs during pregnancy, the respondents know that pregnant women are diagnosed to have hypertension if their blood pressure is more than $140 / 90 \mathrm{mmHg}$, the respondents know that heart disease and high blood sugar

The Level of Maternal Knowledge about Complications.....(Aisyah Apriliciciliana Aryani) 
suffered by the mother during pregnancy will affect the growth and development of the fetus, the respondents know that severe abdominal pain at a young gestational age is a danger sign during pregnancy, the respondents know that anemia is a danger sign during pregnancy, the respondents know that anemic mother is at risk of giving birth to a LBW baby. The level of maternal knowledge is good if the mother answers all the questions correctly. Moreover, variables on maternal characteristics (age, occupation, household expenses, and parity) were also collected. Data analysis was conducted using bivariate analysis to obtain crude odds ratio (OR) and multivariate analysis with the logistic regression model of risk factors to obtain adjusted OR.

\section{Results and Discussion}

\subsection{Results}

Table 1 presents a comparison of the characteristics of respondents in the case group and the control group. It can be seen that the characteristics of the case and control groups are not statistically different in terms of age, occupation, and parity ( $p$-value> 0.05 ), but different in terms of household expenditure ( $p$-value $<0.05$ ).

Table 1. Comparison of Respondents' Characteristics in the Case Group and the Control Group

\begin{tabular}{|c|c|c|c|}
\hline Variable & $\begin{array}{c}\text { Number of Cases } \\
(\%)\end{array}$ & $\begin{array}{c}\text { Number of Controls } \\
(\%)\end{array}$ & p-value \\
\hline Age & & & \\
\hline $\begin{array}{l}<20 \text { years or }>35 \text { years } \\
20-35 \text { tahun }\end{array}$ & $\begin{array}{l}14(27,5) \\
37(72,5)\end{array}$ & $\begin{array}{c}9(17,6) \\
42(82,4)\end{array}$ & 0,343 \\
\hline Occupation & & & \\
\hline Work & $18(35,3)$ & $12(23,5)$ & 0,277 \\
\hline $\begin{array}{c}\text { Does not work } \\
\text { Household Expenses }\end{array}$ & $33(64,7)$ & $39(76,5)$ & \\
\hline $\begin{array}{c}\text { Household Expenses } \\
\quad<\mathrm{Rp} 2.000 .000 \\
\geq \operatorname{Rp} 2.000 .000\end{array}$ & $\begin{array}{c}44(86,3) \\
7(13,7)\end{array}$ & $\begin{array}{l}34(66,7) \\
17(33,3)\end{array}$ & 0,036 \\
\hline Parity & & & \\
\hline $\begin{array}{l}1 \text { or }>4 \text { children } \\
2-4 \text { children }\end{array}$ & $\begin{array}{l}16(31,4) \\
35(68,6)\end{array}$ & $\begin{array}{l}17(33,3) \\
34(66,7)\end{array}$ & 1,000 \\
\hline
\end{tabular}

Table 2 shows that there is a significant relationship between the level of maternal knowledge about complications in pregnancy and the incidence of LBW $(\mathrm{OR}=2.598 ; 95 \% \mathrm{Cl}=$ 1.126-5.995; p-value <0.05).

Table 2. Bivariate Analysis of level of maternal knowledge about complications in pregnancy toward Low Born Weight (LBW) incidence

\begin{tabular}{|c|c|c|c|c|c|c|c|}
\hline \multirow[b]{3}{*}{ Level of Maternal Knowledge } & \multicolumn{4}{|c|}{ LBW } & \multirow{3}{*}{$\mathbf{N}$} & \multirow{3}{*}{ p-value } & \multirow{3}{*}{ OR (95\% Cl) } \\
\hline & \multicolumn{2}{|c|}{ Cases } & \multicolumn{2}{|c|}{ Controls } & & & \\
\hline & $\mathbf{n}$ & $\%$ & $\mathbf{n}$ & $\%$ & & & \\
\hline Low & 24 & 47,1 & 13 & 25,5 & 37 & 0,039 & 2,598 \\
\hline High & 27 & 52,9 & 38 & 74,5 & 65 & 0,039 & $(1,126-5,995)$ \\
\hline
\end{tabular}

Table 3 shows that mothers with a low level of knowledge have 2.5 times greater risk of LBW ( $p$-value $<0.05$; Adj. OR $=2.542 ; 95 \% \mathrm{Cl}=1.032-6.264$ ). In addition, working mothers increase the risk of LBW incidence 3.8 times compared to mothers who do not work ( $p$-value $<0.05$; Adj. OR $=3,788 ; 95 \% \mathrm{Cl}=1,238-11,589$ ), and mothers with household expenditure $<\mathrm{Rp}$. $2,000,000$ have 5.4 times greater risk of LBW incidence ( $p$-value $<0.05 ;$ Adj. OR $=5.382 ; 95 \%$ $\mathrm{Cl}=1.615-17.939)$. 
Table 3. Multivariate Analysis of level of maternal knowledge about complications in pregnancy toward Low Born Weight (LBW) incidence

\begin{tabular}{lccc}
\hline LBW Risk Factors & p-value & $\begin{array}{c}\text { Adjusted } \\
\text { OR }\end{array}$ & 95\% Cl \\
\hline $\begin{array}{l}\text { Maternal Age <20 years or >35 years } \\
\quad \text { Working mother }\end{array}$ & 0,490 & 1,451 & $(0,505-4,166)$ \\
$\quad \begin{array}{l}\text { Mother with household expenses } \\
<\text { Rp 2.000.000 }\end{array}$ & 0,020 & 3,788 & $(1,238-11,589)$ \\
$\begin{array}{l}\text { Parity of 1 or > 4 children } \\
\text { Mother with low level knowledge }\end{array}$ & 0,006 & 5,382 & $(1,615-17,939)$ \\
& 0,321 & 0,619 & $(0,240-1,597)$ \\
& 0,043 & 2,542 & $(1,032-6,264)$
\end{tabular}

\subsection{Discussion}

This study proved that the low level of maternal knowledge about complications in pregnancy increases the risk of LBW incidence. This is supported by previous research which states that the level of maternal knowledge about complications in pregnancy is a risk factor for LBW (5). The low level of maternal knowledge which is potential to increase the risk of LBW incidence is influenced by several other factors such as the level of formal education, mother's age during pregnancy, and access to information sources $(11,16,20)$. Previous researches have shown that there is a relationship between education level and knowledge about danger signs during pregnancy (16). Mothers with a formal education are twice more knowledgeable than others who do not have formal education. This is because mothers with formal education will have good access to information on health services, causes, diseases and treatments. Mothers with formal education are usually able to make optimal use of the information obtained. Regarding the decision making, educated mothers usually have more autonomy to make decisions and also have the ability to use high quality health care services.

Other studies suggest that the maternal age is related to the level of maternal knowledge about the danger signs during pregnancy (11). Older mothers usually have experiences about pregnancy and childbirth which are important sources of information for them. Other predictors that influence women's knowledge of pregnancy danger signs are sources of information. Some researches state that there is a relationship between sources of information and maternal knowledge about the danger signs during pregnancy $(6,9,12)$. Mothers who give birth in health services are 12 times more knowledgeable than mothers who give birth at home. This is due to the information about health care from health workers that the mothers get when giving birth in a health service so that it can facilitate changes in the mother's behavior in preventing complications in future pregnancies (10).

Apart from the low level of maternal knowledge regarding complications in pregnancy, another variable that increases the incidence of LBW were also found, which is working mothers. In this study, after controlling for age and parity, working mothers increase the risk of LBW incidence. The proportion of working mothers in the case group was $35.3 \%$, while in the control group was $23.5 \%$. The results of this study are in line with previous studies (6.15). Physical work done by a mother is often related to additional work other than household work to increase family income. Mothers who work 40 hours or more per week during pregnancy and still have to do household chores usually have insufficient rest time. This can lead to physical and psychological stress. The stress that occurs during pregnancy can cause loss of appetite leading to the insufficient nutrition for mothers and fetus. This situation can increase the risk of giving birth to LBW babies (16).

After controlling for age and parity, mothers with household expenses $<R p$. $2,000,000$ increase the risk of LBW incidence. In this study, respondents with household expenses $<$ Rp. 2,000,000 are closely related to low economic status. The results of this study are in line with previous studies $(5,7,11,14,16)$. Low economic status is directly related to a poor diet due to the inability to buy hygienic food, and inability to attain 
sufficient weight during pregnancy. If the mother has poor diet during pregnancy and fails to achieve a sufficient weight, it can increase the risk of giving birth to LBW babies $(8,15)$.

\section{Conclusion}

It is proven that the low level of maternal knowledge increases the risk of LBW incidence. Other risk factors that can also increase the risk of LBW incidence are mothers who work during pregnancy and maternal household expenses of $<$ Rp. 2,000,000. As a suggestion to increase the level of maternal knowledge about complications during pregnancy, midwives and health workers in the community are expected to improve Antenatal Care (ANC) services at least 4 times during pregnancy, this is because the pregnancy checks carried out properly and regularly not only help increase maternal knowledge but also help early treatment when there are complications that put the mother at risk of giving birth to a baby with low birth weight (LBW). For mothers with a low level of maternal knowledge, it is important that in the future they can pay more attention to their pregnancy, especially if there are indicators that the pregnancy is at high risk. Families and mothers are expected to take care of the health of the mother and baby during pregnancy. For future research, it is expected that the further research on the risk factors of LBW is conducted using a cohort study design to prevent high recall bias.

\section{References}

1. Kemenkes RI. Riset Kesehatan Dasar. Badan Penelitian dan Pengembangan Kesehatan. Jakarta:Kementerian Kesehatan Republik Indonesia. 2018.

2. Dinkes Kota Metro. Profil Kesehatan Kota Metro Tahun 2015. Metro:Dinas Kesehatan Kota Metro. 2016.

3. Putri, Pratitis, Lutfhiya, Wahyuni, dan Tarmali, A. Faktor Ibu terhadap Kejadian Bayi Berat Lahir Rendah. HIGEIA Journal of Public Health Research and Development. 2019;3(1):5562.

4. Fatimah S, Kania N. Hubungan Tingkat Pengetahuan Ibu Hamil Tentang Anemia Dengan Risiko Kejadian BBLR. Midwifery Journal of Galuh University. 2019;1(1):1-8.

5. Setiawan, S. Hubungan Pendapatan Keluarga, Budaya Pantang Makanan, Pengetahuan Gizi dengan Status Gizi Ibu Hamil Trimester III di Wilayah Kerja Puskesmas Slahung Kabupaten Ponorogo. Jurnal Keperawatan Bina Sehat. 2015;9(1):1-10.

6. Fitrianingtyas, Pertiwi, dan Rachmania, W. Faktor-Faktor yang Berhubungan dengan Kejadian Kurang Energi Kronis (KEK) pada Ibu Hamil di Puskesmas Warung Jambu Kota Bogor. HEARTY Jurnal Kesehatan Masyarakat. 2018;6(2):1-8.

7. Kader, M dan Perera, N. Socio-Economic and Nutritional Determinants of Low Birth Weight in India. North American Journal of Medical Sciences. 2018;6(7):302-308.

8. Mayanda, V. Hubungan Status Gizi Ibu Hamil dengan Berat Badan Lahir Rendah (BBLR) RSIA Mutia Sari Kecamatan Mandau. Jurnal Penelitian dan Kajian Ilmiah Menara IImu. 2017;11(74):229-236.

9. Fatimah, Utama, dan Sastri, S. Hubungan Antenatal Care dengan Kejadian Bayi Berat Lahir Rendah pada lbu Aterm di RSUP Dr. M. Djamil Padang. Jurnal Kesehatan Andalas. 2017;6(3):615-620.

10. Herliani, S dan Yustiana, I. Hubungan Status Pekerjaan dan Pendidikan dengan Pengetahuan Ibu Hamil Tentang Tanda Bahaya Kehamilan. Jurnal Obstretika Scientia. 2016;4(1):418-434.

11. Hajri, $F$ dan Aprillia, Y. Hubungan Antara Karakteristik Ibu dengan Pengetahuan Tentang Tanda Bahaya Kehamilan. Jurnal Bidang IImu Kesehatan. 2016;7(1):374-381.

12. Kusumastuti, I. Hubungan Karakteristik Ibu, Paritas dan Sumber Informasi dengan Pengetahuan Ibu Tentang Tanda Bahaya Kehamilan. Jurnal IImiah Kebidanan Indonesia. 2018;8(3):124-132.

13. Dinkes Kota Metro. Profil Kesehatan Kota Metro Tahun 2018. Metro:Dinas Kesehatan Kota Metro. 2019.

14. Chiavarini, M., Bartolucci, F., Gili, A., Pieroni, L., Minelli, L. Effects of Individual and Social Factors on Preterm Birth and Low Birth Weight : Empirical Evidence From Regional Data in Italy. International Journal of Public Health. 2016;57(2):261-268. 
15. Joseph, K., Liston, R., Doods, L., Dahlgren, L., Allen A. Socioeconomic Status Ana Perinatal Outcomes Ni A Setting With Universal Access do Essential Health Care Services. Can Med Assoc Journal. 2017;177(6):583-590.

16. Zendrato, D., Rahayu., Hiswani. Hubungan Faktor Sosiodemografis dan Faktor Kehamilan dengan Kejadian Bayi Berat Lahir Rendah 9BBLR) di RSIA Sri Ratu Medan Tahun 2014. Jurnal Universitas Sumatra Utara. 2016;1(1):1-10. 